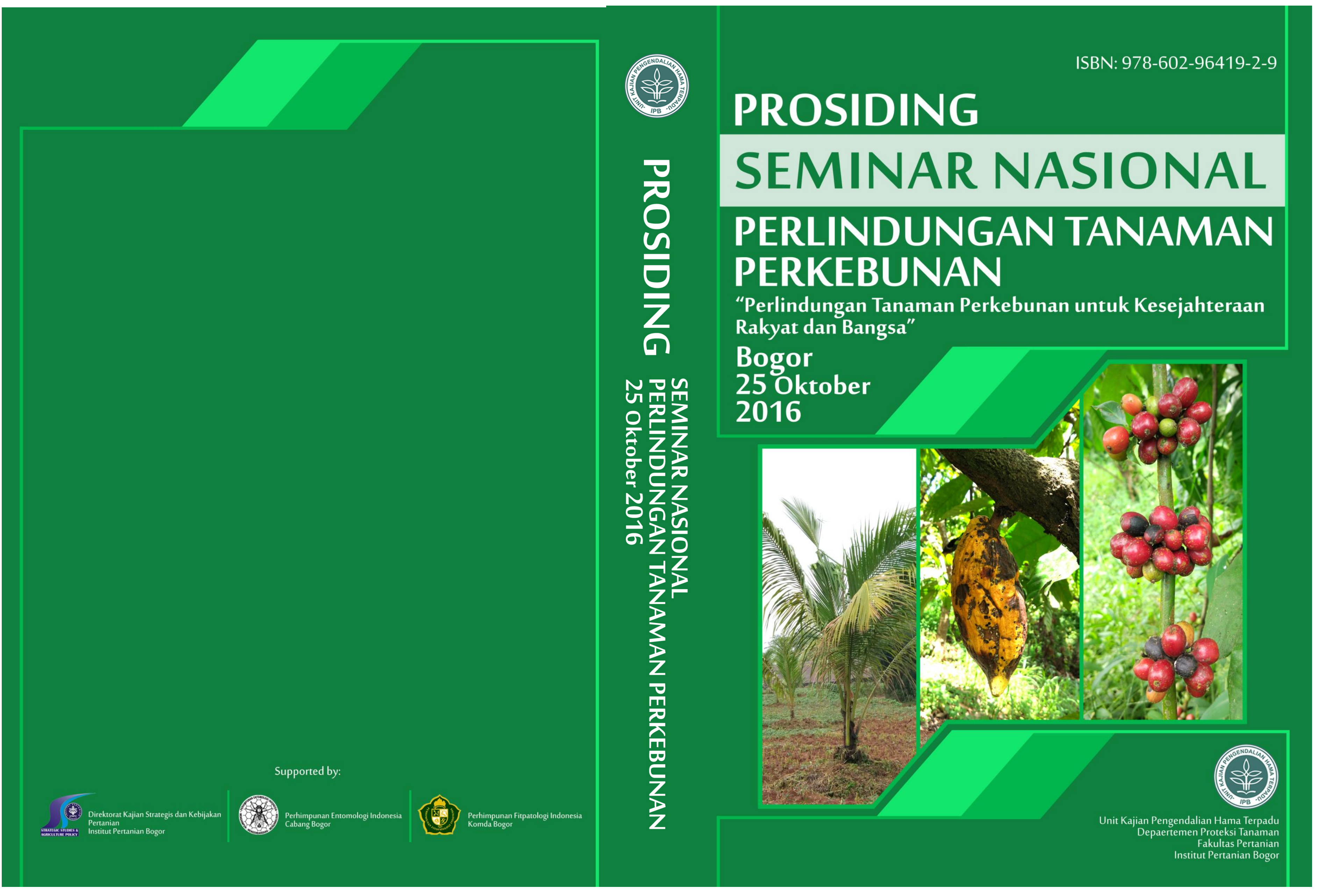




\section{PROSIDING}

\section{SEMINAR NASIONAL}

\section{PERLINDUNGAN TANAMAN PERKEBUNAN}

BOGOR, 25 OKTOBER 2016

Tema

"Perlindungan Tanaman Perkebunan untuk Kesejahteraan Rakyat dan Bangsa"

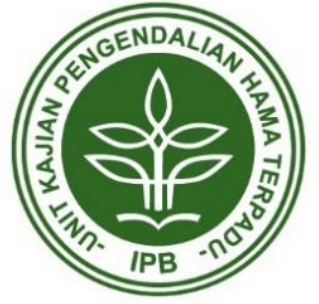

UNIT KAJIAN PENGENDALIAN HAMA TERPADU

DEPARTEMEN PROTEKSI TANAMAN

FAKULTAS PERTANIAN

INSTITUT PERTANIAN BOGOR

2017 


\title{
Tim Penyusun
}

\section{Reviewer:}
Ir. Djoko Prijono, MAgr.Sc
Dr. Ir. Purnama Hidayat, MSc
Dr. Ir. Abdul Munif, MSc.Agr
Dr. Ir. R. Yayi Munara Kusumah, MSi
Dra. Dewi Sartiami, MSi
Dr. Ir. Ruly Anwar, MSi
Dr. Efi Toding Tondok, SP., MSc.Agr
Dr. Ir. Supramana, MSi
Dr. Ir. Giyanto, MSi
Fitrianingrum Kurniawati, SP., MSi
Dr. Ir. I Wayan Winasa, MSi
Dr. Ir. Suryo Wiyono, MSc.Agr
Dr. Ir. Idham Sakti Harahap, MSi
Dr. Ir. Swastiko Priyambodo, MSi
Dr. Ir. Nina Maryana, MSi
Dr. Ir. Teguh Santoso, DEA
Dr. Ir. Pudjianto, MSi

\section{Penyunting Naskah}

Nadzirum Mubin, SP., MSi

Mahardika Gama Pradana, SP

\section{Layout}

Nadzirum Mubin, SP., MSi

\section{Desain Sampul}

Suryadi, SP

\author{
Ucapan Terima Kasih \\ Direktorat Kajian Strategis dan Kebijakan Pertanian (DKSKP) - IPB \\ Perhimpunan Entomologi Indonesia (PEI) Cabang Bogor \\ Perhimpunan Fitopatologi Indonesia (PFI) Komda Bogor
}

\author{
UNIT KAJIAN PENGENDALIAN HAMA TERPADU \\ DEPARTEMEN PROTEKSI TANAMAN \\ FAKULTAS PERTANIAN \\ INSTITUT PERTANIAN BOGOR \\ Telp 0251-8629364; Faks 0251-8629362 \\ Email: pkpht.ipb@gmail.com
}




\title{
Seduhan Daun dan Buah Jarak Pagar (Jatropha curcas L.) untuk Mengendalikan Nematoda Perongga Akar Radopholus similis secara in vitro (Leaves and Fruit Steeping of Physic Nut (Jatropha curcas L.) for in vitro Control of The Root-Burrowing Nematodes Radopholus similis)
}

\section{Ahmed Ibrahimalrashid Yousif Mohamedelamin, Ankardiansyah Pandu Pradana, Muhammad Firdaus Oktafiyanto, Diana Putri, dan Abdul Munif Departemen Proteksi Tanaman, Fakultas Pertanian, Institut Pertanian Bogor Email: abdulmunif@ipb.ac.id}

\begin{abstract}
Radopholus similis is a nematode that infects many plantation crops. Infected plant roots by nematodes will show necrosis symptoms, then rot due to infection of secondary pathogens. Control of $R$. similis that is effective, environmentally friendly, and easy to be performed by the farmers is the key to success in reducing losses by this nematode. Extract of physic nut has been recognized to be effective in controlling some important pests, but there is currently no reports of its effectiveness in controlling $R$. similis. This study aimed to determine the effectiveness of leaves and fruit steeping of physic nut for in vitro control of R. similis. A total of 1:10 (w/v) leaves and fruit of physic nut were steepped, then filtered by a 500 mesh sieve. Steeping was then dripped into a suspension containing $40 \mathrm{R}$. similis. Twenty-four hours after treatment, the number of dead nematodes was observed. The leaves steeping of physic nut could kill up to $70 \%$ of R. similis. Mortality of R. similis treated with steeping of physic nut seeds reached $76.25 \%$. Both steeping applications did not cause damage to the body of nematodes, thus it is presumably that the mortality was due to toxic compounds.
\end{abstract}

Keywords: active compounds, antimicrobial, nematicides, toxic, phenol

\section{PENDAHULUAN}

Fitonematoda Radpholus similis merupakan salah satu patogen penting pada tanaman perkebunan. Nematoda R. similis telah dilaporkan menginfeksi tanaman perkebunan seperti kakao, kopi, teh, lada, kapas, gula bit, dan tebu (O'Bannon 1977; Koshy \& Jasy 1991). Akar tanaman yang terinfeksi R. similis akan menunjukkan gejala nekrosis lalu membusuk. Nekrosis pada akar menyebabkan tanaman menjadi rentan terhadap infeksi patogen tular tanah dari golongan cendawan dan bakteri. Penyerapan unsur hara dan air dari akar juga menjadi terganggu karena rusaknya jaringan akar (O'Bannon \& Nemec 1979; Price 2006; Wang \& Hooks 2009). 
Nematoda R. similis merupakan endoparasit berpindah (migratory endoparasites), dan mampu menyelesaikan seluruh siklus hidupnya di dalam jaringan tanaman (Haegeman et al. 2010). Umumnya R. similis melakukan penetrasi pada bagian ujung akar, namun demikian nematoda ini juga dapat menyerang pada seluruh bagian akar. Saat berada di dalam jaringan akar R. similis memakan sitoplasma dari sel yang berada di dekatnya, sehingga menyebabkan jaringan akar berongga. Karena gejala yang ditumbulkan tersebut R. similis juga dikenal sebagai nematoda perongga akar (Valette et al. 1998; Jones et al. 2013).

Nematoda betina dan larva merupakan stadia infektif $R$. similis. Nematoda jantan mengalami degenerasi yang menyebabkan stilet tidak berkembang, sehingga menyebabkan nematoda jantan tidak bersifat parasit (Van Weerdt 1960). Petani biasanya menggunakan bahan kimia sintetis untuk mengendalikan R. similis. Aplikasi bahan kimia sintetis dapat diganti atau dikurangi dengan penggunaan ekstrak tanaman yang lebih ramah lingkungan. Salah satu ekstrak tanaman tersebut adalah ekstrak daun dan buah jarak pagar (Adebowale \& Adedire 2006; Khalil 2014).

Tanaman jarak pagar banyak dibudidayakan karena bijinya berpotensi sebagai sumber minyak dalam pembuatan biodiesel (Silitonga et al. 2011; Gonzáles 2016). Minyak biji jarak pagar juga dilaporkan efektif sebagai larvasida, anti-oviposisi dan ovisida terhadap larva nyamuk Aedes albopictus (Adebowale \&Adedire 2006; Kumar \& Sharma 2008; Kovendan et al. 2011). Tukimin dan Karmawati (2012) melaporkan minyak bungkil biji jarak pagar dapat digunakan sebagai biopestisida terhadap Helicoverpa armigera Hũbner. Meskipun telah dilaporkan efektif sebagai pestisida nabati terhadap beberapa hama dan patogen, namun sampai saat ini penelitian mengenai keefektifan ekstrak daun dan biji jarak pagar untuk mengendalikan populasi nematoda $R$. similis belum dilakukan. Tujuan penelitian ini yaitu mengetahui keefektifan seduhan daun dan biji jarak pagar untuk mengendalikan nematoda $R$. similis secara in vitro.

\section{BAHAN DAN METODE}

\section{Penyediaan Ekstrak Daun dan Buah Jarak Pagar}

Daun dan buah jarak pagar diperoleh dari kebun Balai Penelitian Tanaman Industri dan Penyegar, Parungkuda, Sukabumi, Jawa Barat. Bahan (daun dan buah jarak pagar) ditimbang kemudian masing-masing dicampur akuades dengan perbandingan 1:10 (w/v). Campuran tersebut kemudian direbus sampai mendidih. Hasil rebusan kemudian disaring menggunakan saringan berukuran 500 mesh agar didapatkan suspensi yang bersih. Suspensi yang diperoleh kemudian diukur keasamannya menggunakan kertas pH (Tyas et al. 2014).

\section{Penyediaan Nematoda Perongga Akar R. similis}

Nematoda R. similis yang digunakan merupakan koleksi Laboratorium Nematologi Tumbuhan, IPB. Nematoda berasal dari akar tanaman pisang yang diinfeksi oleh $R$. similis. 


\section{Uji Potensi Ekstrak Daun dan Buah Jarak Pagar dalam Mengendalikan R. similis}

Sebanyak 40 ekor nematoda $R$. similis diletakkan pada $5 \mathrm{~mL}$ akuades di dalam cawan petri dengan diameter $4 \mathrm{~cm}$. Suspensi nematoda tersebut kemudian ditetesi dengan $5 \mathrm{~mL}$ ekstrak daun atau buah jarak pagar, sebagai kontrol suspensi R. similis ditetesi dengan $5 \mathrm{~mL}$ akuades. Setiap perlakuan diulang sebanyak 2 kali. Dua puluh empat jam setelah perlakuan nematoda disaring menggunakan saringan 500 mesh dan dibilas menggunakan akuades sampai ekstrak daun dan buah jarak pagar hilang. Nematoda yang telah dicuci kemudian diletakkan pada cawan sirakus dan didiamkan 60 menit agar nematoda aktif kembali. Setelah 60 menit dilakukan pengamatan terhadap mortalitas $R$. similis dari setiap perlakuan. Nematoda yang tidak bergerak sama sekali atau memiliki bentuk tubuh yang lurus dihitung sebagai nematoda yang mati (Lorimer et al. 1996).

\section{HASIL DAN PEMBAHASAN}

Jarak pagar merupakan salah satu tanaman yang mudah dibudidayakan, dapat tumbuh dengan baik pada lingkungan tropis, dan memiliki daya adaptasi yang tinggi pada lahan kering (Mulyani et al. 2006). Saat ini jarak pagar banyak dimanfaatkan sebagai sumber bahan bakar karena memiliki kandungan minyak yang tinggi, namun biaya produksinya lebih rendah dibandingkan dengan minyak nabati lainnya (Openshaw 2000; King et al. 2009). Selain dimanfaatkan sebagai sumber bahan bakar, jarak pagar juga banyak dimanfaatkan pada sektor pertanian dan obat-obatan (Haas \& Mittelbach 2000; Kumar \& Sharma 2008).

Tanaman jarak pagar dipilih sebagai alternatif pengendalian terhadap $R$. similis karena ekstrak tanaman ini sebelumnya telah dilaporkan efektif sebagai pestisida nabati terhadap beberapa hama penting (Adebowale \& Adedire 2006; Kovendan et al. 2011). Daun, buah, biji, dan akar jarak pagar dilaporkan mengandung senyawa aktif seperti $\beta$-sitosterol, flavonoid, forbol ester dan stigmasterol. Kandungan flavonoid dan forbol ester yang terkandung dalam tanaman ini berpotensi dimanfaatkan sebagai antimikroba (MartinezHerrera et al. 2006; Salimon \& Abdullah 2008; Joshi et al. 2011).

Seduhan daun jarak pagar memiliki warna hijau muda dan keruh, tidak berbau, dan tidak kental. Seduhan biji jarak pagar juga memiliki karakter yang hampir mirip, yaitu berwarna hijau muda (namun tidak keruh), tidak berbau, dan tidak kental. Kedua hasil seduhan tersebut memiliki pH antara 6 - 7. Lebih lanjut hasil seduhan daun dan buah jarak pagar disajikan pada Gambar 1.

Selama 24 jam setelah perlakuan tidak ditemukan nematoda mati pada kontrol. Nematoda yang diberi perlakuan dengan seduhan daun jarak pagar mortalitasnya mencapai $70 \%$. Seduhan buah jarak pagar memberikan nilai mortalitas yang lebih tinggi dibandingkan dengan seduhan daun. Mortalitas nematoda yang diberi perlakuan dengan seduhan buah jarak pagar mencapai 76.25\% (Tabel 1). 


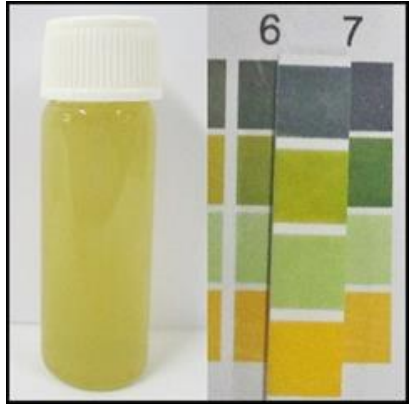

a

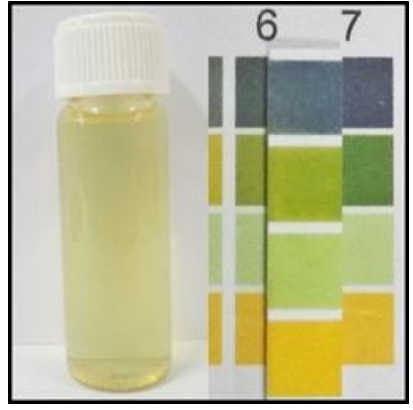

b

Gambar 1 Seduhan (a) daun jarak pagar dengan warna hijau muda keruh dengan $\mathrm{pH}$ antara $6-7$, dan (b) buah jarak pagar dengan warna hijau muda dengan $\mathrm{pH}$ antara $6-7$

Tabel 1 Mortalitas R. similis yang diberi perlakuan menggunakan seduhan daun dan buah jarak pagar

\begin{tabular}{lccccc}
\hline \multirow{2}{*}{ Perlakuan } & \multicolumn{2}{c}{$\sum$ Nematoda hidup } & \multicolumn{2}{c}{$\sum$ Nematoda mati } & \multirow{2}{*}{ Mortalitas (\%) } \\
\cline { 2 - 5 } & Ulangan 1 & Ulangan 2 & Ulangan 1 & Ulangan 2 & \\
\hline Seduhan daun & 11 & 13 & 29 & 27 & $70 \pm 1.41$ \\
Seduhan buah & 7 & 12 & 33 & 28 & $76.25 \pm 3.53$ \\
Kontrol & 40 & 40 & 0 & 0 & 0 \\
\hline
\end{tabular}

Hasil pengamatan terhadap nematoda yang mati menunjukkan tidak terdapat kerusakan tubuh pada nematoda (Gambar 2). Kondisi tubuh nematoda yang tidak rusak menunjukkan bahwa nematoda mati bukan karena enzim, namun diduga karena adanya senyawa racun. Pernyataan ini diperkuat oleh beberapa penelitian yang menyatakan biji jarak pagar mengandung senyawa curcin dan forbol ester yang bersifat toksik dan antinutrisi (Lin et al. 2003; Ahmed \& Salimon 2009; Li et al. 2010). Bungkil sisa pengepresan jarak pagar juga diketahui mengandung curcin yang bersifat sangat toksik. Curcin dapat menyebabkan iritasi pada mata, dan keracunan pada hewan peliharaan (Stirpe et al. 1976; Devappa et al. 2010; Lin et al. 2010).

Kandungan senyawa fenol yang terdapat pada jarak pagar diduga juga berperan dalam meningkatkan mortalitas $R$. similis. Senyawa fenol dapat bekerja sebagai antimikroba dengan cara meracuni protoplasma. Mekanisme lain dari senyawa fenol sebagai antimikroba adalah dengan merusak dan menembus dinding sel mikroba, dan mengendapkan protein sel mikroba. Senyawa fenol merupakan senyawa dengan molekul besar yang mampu menginaktifkan enzim-enzim penting di dalam sel mikroba meskipun pada konsentrasi rendah (Dorman \& Deans 2000; Puupponen-Pimiä et al. 2001). Senyawasenyawa antimikroba yang terkandung pada jarak pagar berbeda jumlahnya tergantung pada varietas, klon, maupun lokasi budidaya (Igbinosa et al. 2009; Namuli et al. 2011; Roach et al. 2012). 

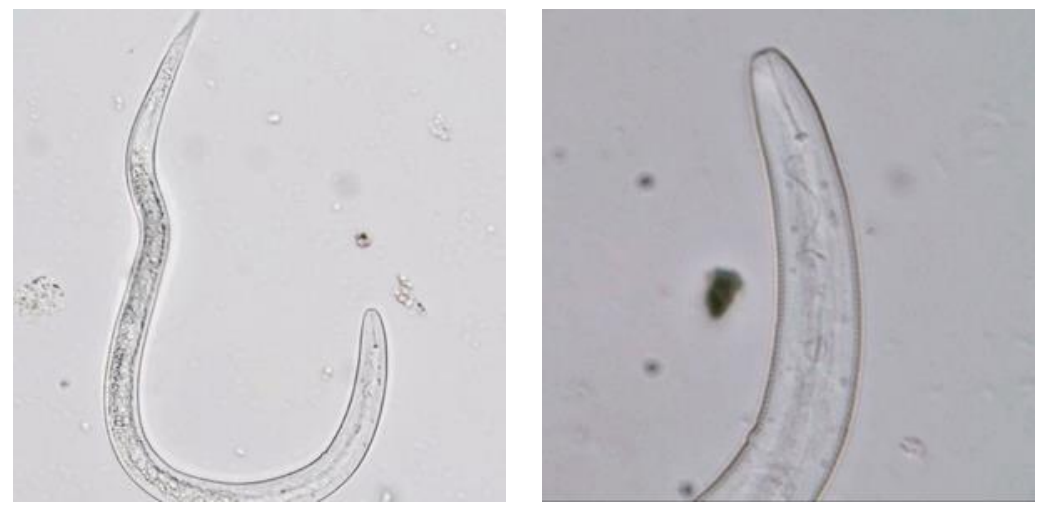

Gambar 2 Nematoda R. similis yang mati karena perlakuan seduhan daun dan buah jarak pagar tidak mengalami kerusakan tubuh

\section{KESIMPULAN}

Penelitian ini memberikan informasi baru bahwa seduhan daun dan buah jarak pagar memiliki potensi untuk mengendalikan nematoda perongga akar $R$. similis secara in vitro. Seduhan buah jarak pagar dengan konsentrasi 50\% lebih efektif dalam meningkatkan mortalitas $R$. similis dibanding dengan seduhan daun jarak pagar pada konsentrasi yang sama.

\section{UCAPAN TERIMA KASIH}

Penulis mengucapkan terima kasih kepada Dr. Rita Harni dari Balai Penelitian Tanaman Industri dan Penyegar, Sukabumi, atas bantuannya dalam memberikan sampel tanaman jarak pagar sebagai bahan utama penelitian.

\section{DAFTAR PUSTAKA}

Adebowale K, Adedire C. 2006. Chemical composition and insecticidal properties of the underutilized Jatropha curcas seed oil. African Journal of Biotechnology. 5(10):901906.

Ahmed WA, Salimon J. 2009. Phorbol ester as toxic constituents of tropical Jatropha curcas seed oil. European Journal of Scientific Research. 31(3):429-436.

Devappa RK, Makkar HP, Becker K. 2010. Jatropha toxicity-a review. Journal of Toxicology and Environmental Health, Part B. 13(6):476-507. Doi: http://dx.doi.org/10.1080/10937404.2010.499736.

Dorman H, Deans S. 2000. Antimicrobial agents from plants: antibacterial activity of plant volatile oils. Journal of Applied Microbiology. 88(2):308-316. Doi: http://dx.doi.org/10.1046/j.1365-2672.2000.00969.x. 
Gonzáles NFC. 2016. International experiences with the cultivation of Jatropha curcas for biodiesel production. Energy. 112:1245-1258. Doi: http://dx.doi.org/10.1016/j.energy.2016.06.073.

Haas W, Mittelbach M. 2000. Detoxification experiments with the seed oil from Jatropha curcas L. Industrial Crops and Products. 12(2):111-118. Doi: http://dx.doi.org/10.1016/S0926-6690(00)00043-1.

Haegeman A, Elsen A, De Waele D, Gheysen G. 2010. Emerging molecular knowledge on Radopholus similis, an important nematode pest of banana. Molecular Plant Pathology. 11(3):315-323. Doi: http://dx.doi.org/10.1111/j.1364-3703.2010.00614.x.

Igbinosa O, Igbinosa E, Aiyegoro O. 2009. Antimicrobial activity and phytochemical screening of stem bark extracts from Jatropha curcas (Linn). African Journal of Pharmacy and Pharmacology. 3(2):058-062.

Jones JT, Haegeman A, Danchin EG, Gaur HS, Helder J, Jones MG, Kikuchi T, ManzanillaLópez R, Palomares-Rius JE, Wesemael WM. 2013. Top 10 plant-parasitic nematodes in molecular plant pathology. Molecular Plant Pathology. 14(9):946-961. Doi: http://dx.doi.org/10.1111/mpp.12057.

Joshi C, Mathur P, Khare S. 2011. Degradation of phorbol esters by Pseudomonas aeruginosa PseA during solid-state fermentation of deoiled Jatropha curcas seed cake. Bioresource Technology. 102(7):4815-4819. Doi: http://dx.doi.org/10.1016/j.biortech.2011.01.039.

Khalil MS. 2014. Bright future with nematicidal phytochemicals. Biology and Medicine. 6(2):13. Doi: http://dx.doi.org/10.4172/0974-8369.1000e104.

King AJ, He W, Cuevas JA, Freudenberger M, Ramiaramanana D, Graham IA. 2009. Potential of Jatropha curcas as a source of renewable oil and animal feed. Journal of Experimental Botany. 60(10):2897-2905. Doi: http://dx.doi.org/10.1093/jxb/erpo25.

Koshy P, Jasy T. 1991. Host preference of the burrowing nematode, Radopholus similis populations from India. Indian Journal of Nematology. 21(1):39-51.

Kovendan K, Murugan K, Vincent S, Kamalakannan S. 2011. Larvicidal efficacy of Jatropha curcas and bacterial insecticide, Bacillus thuringiensis, against lymphatic filarial vector, Culex quinquefasciatus Say (Diptera: Culicidae). Parasitology research. 109(5):1251-1257. Doi: http://dx.doi.org/10.1007/s00436-011-2368-6.

Kumar A, Sharma S. 2008. An evaluation of multipurpose oil seed crop for industrial uses (Jatropha curcas L.): a review. Industrial Crops and Products. 28(1):1-10. Doi: http://dx.doi.org/10.1016/j.indcrop.2008.01.001.

Li C-Y, Devappa RK, Liu J-X, Lv J-M, Makkar H, Becker K. 2010. Toxicity of Jatropha curcas phorbol esters in mice. Food and Chemical Toxicology. 48(2):620-625. Doi: http://dx.doi.org/10.1016/j.fct.2009.11.042.

Lin J, Chen Y, Xu Y, Yan F, Tang L, Chen F. 2003. Cloning and expression of curcin, a ribosome-inactivating protein from the seeds of Jatropha curcas. Acta Botanica Sinica. 45(7):858-863. 
Lin J, Zhou X, Wang J, Jiang P, Tang K. 2010. Purification and characterization of curcin, a toxic lectin from the seed of Jatropha curcas. Preparative Biochemistry \& Biotechnology. 40(2):107-118. Doi: http://dx.doi.org/10.1080/10826060903558588.

Lorimer SD, Perry NB, Foster LM, Burgess EJ, Douch PG, Hamilton MC, Donaghy MJ, McGregor RA. 1996. A nematode larval motility inhibition assay for screening plant extracts and natural products. Journal of Agricultural and Food Chemistry. 44(9):28422845. Doi: http://dx.doi.org/10.1021/jf9602176.

Martinez-Herrera J, Siddhuraju P, Francis G, Davila-Ortiz G, Becker K. 2006. Chemical composition, toxic/antimetabolic constituents, and effects of different treatments on their levels, in four provenances of Jatropha curcas L. from Mexico. Food Chemistry. 96(1):80-89. Doi: http://dx.doi.org/10.1016/j.foodchem.2005.01.059.

Mulyani A, Agus F, Allelorung D. 2006. Potensi sumber daya lahan untuk pengembangan jarak pagar (Jatropha curcas L.) di Indonesia. Jurnal Litbang Pertanian. 23(4):130-138.

Namuli A, Abdullah N, Sieo C, Zuhainis S, Oskoueian E. 2011. Phytochemical compounds and antibacterial activity of Jatropha curcas Linn. extracts. Journal of Medicinal Plants Research. 5(16):3982-3990.

O'Bannon J. 1977. Worldwide dissemination of Radopholus similis and its importance in crop production. Journal of Nematology. 9(1):16-25.

O'Bannon J, Nemec S. 1979. The response of Citrus limon seedlings to a symbiont, Glomus etunicatus, and a pathogen, Radopholus similis. Journal of Nematology. 11(3):270-275.

Openshaw K. 2000. A review of Jatropha curcas: an oil plant of unfulfilled promise. Biomass and Bioenergy. 19(1):1-15. Doi: http://dx.doi.org/10.1016/Sog61-9534(00)00019-2.

Price NS. 2006. The banana burrowing nematode, Radopholus similis (Cobb) Thorne, in the Lake Victoria region of East Africa: its introduction, spread and impact. Nematology. 8(6):801-817. Doi: http://dx.doi.org/10.1163/156854106779799240.

Puupponen-Pimiä R, Nohynek L, Meier C, Kähkönen M, Heinonen M, Hopia A, OksmanCaldentey KM. 2001. Antimicrobial properties of phenolic compounds from berries. Journal of Applied Microbiology. 90(4):494-507. Doi: http://dx.doi.org/10.1046/j.13652672.2001.01271.x.

Roach JS, Devappa RK, Makkar HP, Becker K. 2012. Isolation, stability and bioactivity of Jatropha curcas phorbol esters. Fitoterapia. 83(3):586-592. Doi: http://dx.doi.org/10.1016/j.fitote.2012.01.001.

Salimon J, Abdullah R. 2008. Physicochemical properties of Malaysian Jatropha curcas seed oil. Sains Malaysiana. 37(4):379-382.

Silitonga A, Atabani A, Mahlia T, Masjuki H, Badruddin IA, Mekhilef S. 2011. A review on prospect of Jatropha curcas for biodiesel in Indonesia. Renewable and Sustainable Energy Reviews. 15(8):3733-3756. Doi: http://dx.doi.org/10.1016/j.rser.2011.07.011.

Stirpe F, Pession-Brizzi A, Lorenzoni E, Strocchi P, Montanaro L, Sperti S. 1976. Studies on the proteins from the seeds of Croton tiglium and of Jatropha curcas-toxic properties and inhibition of protein synthesis in vitro. Biochemical Journal. 156(1):1-6. 
Tukimin S, Karmawati E. 2012. Pengaruh minyak bungkil biji jarak pagar terhadap mortalitas dan peneluran Helicoverpa armigera Hũbner. Jurnal Penelitian Tanaman Industri. 18(2):54-59.

Tyas DW, Wahyuni D, Hariyadi S. 2014. Perbedaan toksisitas ekstrak, rebusan dan rendaman daun pepaya (Carica papaya L.) terhadap mortalitas larva nyamuk Aedes aegypti L. Pancaran Pendidikan. 3(1):59-68.

Valette C, Andary C, Geiger J, Sarah J, Nicole M. 1998. Histochemical and cytochemical investigations of phenols in roots of banana infected by the burrowing nematode Radopholus similis. Phytopathology 88(11):1141-1148. Doi: http://dx.doi.org/10.1094/PHYTO.1998.88.11.1141.

Van Weerdt L. 1960. Studies on the biology of Radopholus similis (Cobb, 1893) Thorne, 1949. Nematologica. 5(1):43-52. Doi: http://dx.doi.org/10.1163/187529260X00244.

Wang K-H, Hooks CR. 2009. Plant-parasitic nematodes and their associated natural enemies within banana (Musa spp.) plantings in Hawaii. Nematropica. 39(1):57-73. 